\title{
THE ACCOUNTABILITY AND COST EFFECTIVENESS OF REGULATORY POLICY: THE CASE OF THE BANKING SECTOR*
}

\author{
Kupryashin Gennady \\ $\mathrm{PhD}$ in Political Science, Professor in the Department of Management Theory and Technologies \\ of the School of Public Administration, Lomonosov Moscow State University. \\ Address: 27 Lomonosov Prospekt, Building 4, Moscow, 119192. \\ E-mail: gkupryashin@gmail.com.
}

\section{Bodrov Yaroslav}

graduate student in the Department of Management Theory and Technologies in the School of Public Administration, Lomonosov Moscow State University.

Address: 27 Lomonosov Prospekt, Building 4, Moscow, 119192.

E-mail: yarosbodrov7@gmail.com.

\begin{abstract}
This paper examines the contradiction between the accountability and cost effectiveness of regulatory policy at a time when the "delegation" model is dominant. Using the banking sector as a case study, it shows the relationship between formal and informal practices during volatile international and domestic market conditions. The authors analyze the practice of regulation by the Bank of Russia (Bank Rossii), the central bank of the Russian Federation, of a minimum level of capital and risk management at a particular commercial bank. The analysis is based on regulations and consolidated statistical data from the central bank and reporting data from lending institutions. The authors' principal conclusions show that, given the closed nature of the decisionmaking process, banking-sector actors set up unofficial interaction channels in addition to legal ones, and this intensifies distrust in the market. Hence the capital ratio standard that is used in the reporting documents of lending institutions is not an accurate indicator of a bank's financial stability. Given the weak institutions, the tasks of cost effectiveness are better served by a hybrid model of accountability that is based on a balance between delegation and hands-on participation. This model limits the actors' ability to unilaterally influence the regulator and thereby reduces the systemic risks of the banking sector.
\end{abstract}

Keywords: "delegation" and "participation" models of accountability; regulatory policy; level of trust; regulation of the banking sector; central bank policy; capital ratio.

$A \mathrm{n}$ instrumental vision of the institution of public regulatory policy regards it as an indispensable form for achieving desirable and predictable effects (Salamon, 2002). At the same time, one of the key ideas of institutionalism lies in

* Translated by Steven Shabad. 
affirming preferences of interests and values in regard to institutional forms and policy outcomes (Olsen, 2010). It turns out that an assessment of the consequences of activities in terms of the feasibility of regulatory decisions that measures the implementation of predetermined and formally stated objectives is inadequate for understanding the nature of interaction between the regulator and the regulated. The use of the criterion of accountability makes it possible to identify the procedural weaknesses of regulatory action and to focus on the risks of growth of the shadow economy. Specifically, in an undeveloped institutional environment, the mechanisms of accountability boil down primarily to prohibitions and sanctions. Under these conditions, secretive decision-making contributes to increased uncertainty in the regulatory mechanism and, simultaneously, stimulates the use not only of formal but also informal methods of combating its dysfunctions. Parallel structures (informal institutions) take shape where the key tool for implementing rules consists of negotiations by participants in regulatory policy that result in an increase in exceptions to the rules.

This paper considers accountability as a specific type of relation that denotes a dominant status of one actor over another in the process of interaction; the right of one actor to participate in another's activities, influence decision-making, and receive an accounting of the performance of obligations. Therefore the accountability of actors who are the objects of regulatory policy is a specific state of administrative relations in which the regulator has the right to audit the activities of market actors, including the right to cancel or suspend their administrative acts, while the latter are required to provide the necessary opportunities for such audits and report on their activities. Accountability characterizes the activities in terms of following formal rules, based on the criterion of comparing actual behavior with prescribed standards; hence the focus is not on outcomes but on process.

Accountability in this interpretation implies that the regulator has the right to include the actors of economic relations in the network of standards, to judge whether they are fulfilling their obligations in accordance with these standards, and to impose sanctions if it decides that the prescribed obligations have not been fulfilled. This incorporates the interaction between the competent government authorities and those who ensure the exercise of their administrative powers, including by means of informational support. This interaction is based on the legitimacy both of the operational standards of accountability and the powers of the parties to the interaction, in which one party exercises specific powers while the other supports their accountability (Oakerson, 1989).

In analyzing accountability relationships, the authors will use the delegation and participation models defined by Ruth W. Grant and Robert O. Keohane (2005). These models show that the "standards/information/powers/sanctions" mechanism operates in democratic countries when society has the ability to hold power-wielders accountable for abuses of power either as the source of that power (the delegation model) or as the body affected by it (the participation model) or both. Therefore the concept of accountability implies that the actors being held accountable must act in ways consist with existing standards of behavior or the prescribed sanctions (penalties) will be imposed on them for their failure to do so. Norms (standards) and sanctions are connected by means of the relevant com- 
munications channels, through which the necessary information is regularly provided: in one direction, on the substance of the norms; in the other, on the degree of conformity (divergence) between the norm and real actions.

However, the legitimacy of standards, sanctions, and powers is apt to decline in an environment of weak institutions with a low level of confidence in the actual procedure for producing regulatory decisions. It should be noted here that, in essence, the external accountability that is considered within the framework of regulatory policy is an institutionally constructed communication that provides an exchange of resources between the administrators of government agencies and market actors. The economic actors have important resources that the administrators need, including information on their projects and the capacity to act. The administrators have their own resources, in particular, powers, finances, and support that are essential for the economic actors. Accountability in this sense may also be represented as a barter relationship, in which each party makes deals with the other party to exchange its needs and resources (Khillman, 2009).

Delegation performs its functions under a developed institutional system. This accountability model is not practiced without transparent procedures; that is, its implementation imposes a requirement that transparent rules be followed not only by the regulated party but also by the regulator. This requirement can be fulfilled in an environment of weak institutions if associations of businesses and specific market participants are included in the process of working out accountability standards, which implies a blurring of the boundaries between the delegation model and the participation model. Such a hybrid accountability model, by using negotiations between governmental and nongovernmental entities with a stake in joint efforts to achieve a mutually acceptable result, may include a filter to screen for the effectiveness of planned regulatory measures.

In order to achieve accountability that meets the criteria of democracy and simultaneously promotes effective government regulation, it is essential to find a balance between specific mechanisms of external and intra-organizational accountability. For this task to be accomplished, there must be not only institutions of accountability that are able to combine oversight of the use of delegated powers and intra-organizational accountability of administrative managers, but also well-developed consultative channels of communication and consensus decision-making procedures. In this connection we should note that various accountability mechanisms are suitable for the established practices of economic and political actors.

A prime example of such practices in Russia, in our view, is the interaction between commercial banks and their regulator, the Bank of Russia (Bank Rossii), the central bank of the Russian Federation (RF).

We will consider the typical practice of commercial banks that is the subject of the government's regulatory policy. Banking activities involve an intertwining of the interests of different actors that have various resources (economic, political, administrative, informational, analytical, etc.), both with regard to assessing their own risks and with regard to influencing the regulator's policy. The banking business is an activity with high risk, which does not always lend itself to a precise assessment. The reasons for this are, on the one hand, the low transpar- 
ency of the banking sector and, on the other, the lack of incentives for linking information on the level of stability of a specific commercial bank with financial decision-making by economic actors. The level of detail of the information that is provided (e.g., the disclosure of the amount of loan loss reserves; information on unprofitable or nonperforming assets, etc.) prevents a potential investor or shareholder from adequately assessing the degree of acceptance of risk by a commercial bank.

The practice of banking activities proceeds from the need to re-allocate risk in the economy, when a bank accumulates risks for which it receives payment from other economic actors: "Banks are regarded not simply as risk-bearing companies but as companies for which risks are sources of profit" (Vine, 2014). For a potential depositor or creditor, putting available funds in a bank (in deposit or settlement accounts) is a method of saving money. A commercial bank invests these funds in assets with various levels of risk, thereby transferring this risk to the creditors and depositors. In an environment with a nontransparent financial market, banks that have a strong appetite for risk may offer a higher interest on deposit accounts, which will be a key reference point for potential depositors. As a result, banks with a small proportion of risky transactions find themselves in a worse market position. As researchers have noted, the stability of the banking system is largely determined not only by the level of competition and a display of sustainable growth but also by the aggregate level of risk (Zrazhevskii, 2007). It is revealing that Russian law highlights the maintenance of the stability of the banking system and the protection of the interests of depositors and creditors as the principal objectives of banking regulation and banking oversight (Federal'nyi zakon , 2014). Thus the functions of accountability include providing information that is required not only for legal regulation but also for enabling investors and depositors to make well thought-out financial decisions by reasonably assessing the risk level.

Accountability, however, is not an equitable interaction. On the one hand, the regulator has the right to prescribe rules and sanctions in order to implement accountability mechanisms. On the other hand, there is an informational asymmetry when the measure of knowledge about the level of risk of a commercial bank's transactions diminishes along the chain: bank - regulator - investor (depositor). Conditions arise that promote a gap between public (external) accountability and its latent mechanisms. From the standpoint of external accountability, its actors must fulfill the directives of the regulator in good faith. The latter, however, may orient itself in its activities not only toward standards and rules but also toward the interests of various regulatory actors. Regulatory actors (subjects) that have substantial political resources may construct back-channels of interaction with regulatory authorities, thereby making it possible to influence their decisions, including guarantees of assistance in the event their financial situation deteriorates. In addition, there are state banks in the Russian banking market, which have access to relatively cheap resources (e.g., by borrowing funds from state companies). In obtaining preferences, major players are interested in preserving the backchannel mechanisms of regulatory policy, based on informal practices of harmonizing interests. The exceptions in regulatory policy become the rule when formal 
standards and requirements are mandatory only for actors with a low capacity for political influence, which increases the costs to end users of their services and reduces the overall effectiveness of the banking sector.

This situation in the banking sector is exacerbated by the following factor. The mobilization of resources for risky but highly profitable transactions utilizes funds from less profitable markets, which unbalances the financial system as a whole. Naturally, the regulator responds with directives seeking to limit the potential risks of depositors and creditors. But a tight regulatory policy generates additional costs for stakeholders. Banks are forced to increase expenses by fulfilling the regulator's requirements, which becomes an additional burden for the bank's borrowers and clients, since the price of banking services rises. The ratio of administrative and managerial costs to assets in a five-year period in Russia's banking system increased by 125 percent, while it rose by 8 percent in Germany and 5 percent in China. In the United States this ratio fell by 1 percent and in India it dropped 23 percent (Tosunyan, 2014). In addition, the increase in restrictive actions by the regulator provides new incentives for actors with political resources of influence to seek new back-channels of interaction.

At the same time, major players have an interest in exceptions to the decisions that have a substantial impact on their business. But it is precisely the routine decisions of the central bank (revising the calculation of guidelines, imposing additional itemizations, clarifying specific rules) that transform the banking business into an endless fulfillment of new requirements from the regulator. This problem is typical not only for Russia. Arthur Burns, the former chairman of the Board of Governors of the Federal Reserve System in the United States, described banking regulation as "a legal thicket in which one loses one's mind," as a system whose components "compete in the absence of clarity" (Sinkey, 2007). The low level of transparency of the regulatory process undermines confidence in the formal procedures of accountability, which in turn increases the impetus toward back-channels of interaction.

The authors of this paper find it helpful to consider the risks of the established accountability mechanism in the case of the regulation of a minimum level of capital and the quality of management of bank risks at a particular commercial bank. The purpose of this analysis is to define specific markers for a transition to an institution of accountability oriented toward implementing a participation model in an environment where the banking sector has structural imbalances.

During the current stage of development of Russia's banking sector, the following processes can be identified as reinforcing its structural imbalances.

1 . The market share controlled by a small group of major lending institutions is continually increasing (Timofeyeva, 2012), which is illustrated by Figures 1 and 2 .

All five of Russia’s largest banks (Sberbank, VTB [Vneshtorgbank], Gazprombank, VTB-24, Bank of Moscow) are banks with controlling government shares. In addition, the banks in which government bodies are present as shareholders automatically receive special status. This consists of a guaranteed market share; benevolent treatment from regulatory agencies; and an image, so rare in the Russian market, of a "reliable entity" with a transparent ownership structure (Artemev, 
2010). Moreover, in the current unstable macroeconomic situation the chief reference point for most customers in selecting a financial intermediary is the amount of its capital and its market share. The latter enables thee major banks to dictate their own terms to other market participants and strengthens their negotiating positions in interacting with the regulator.

Figure 1

Size of portfolio of loans granted to nonfinancial entities, (billions of rubles)

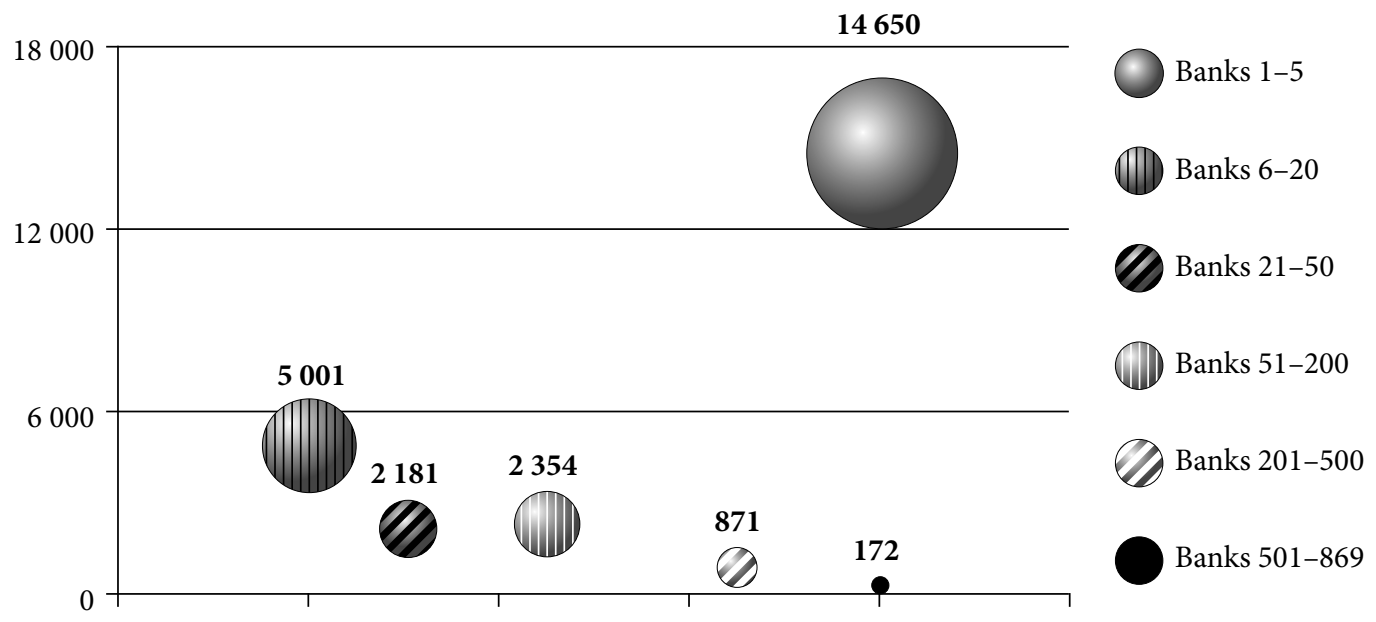

Source: Bank of Russia (2014d).

Amount of deposits by individuals,

Figure 2 (billions of rubles)

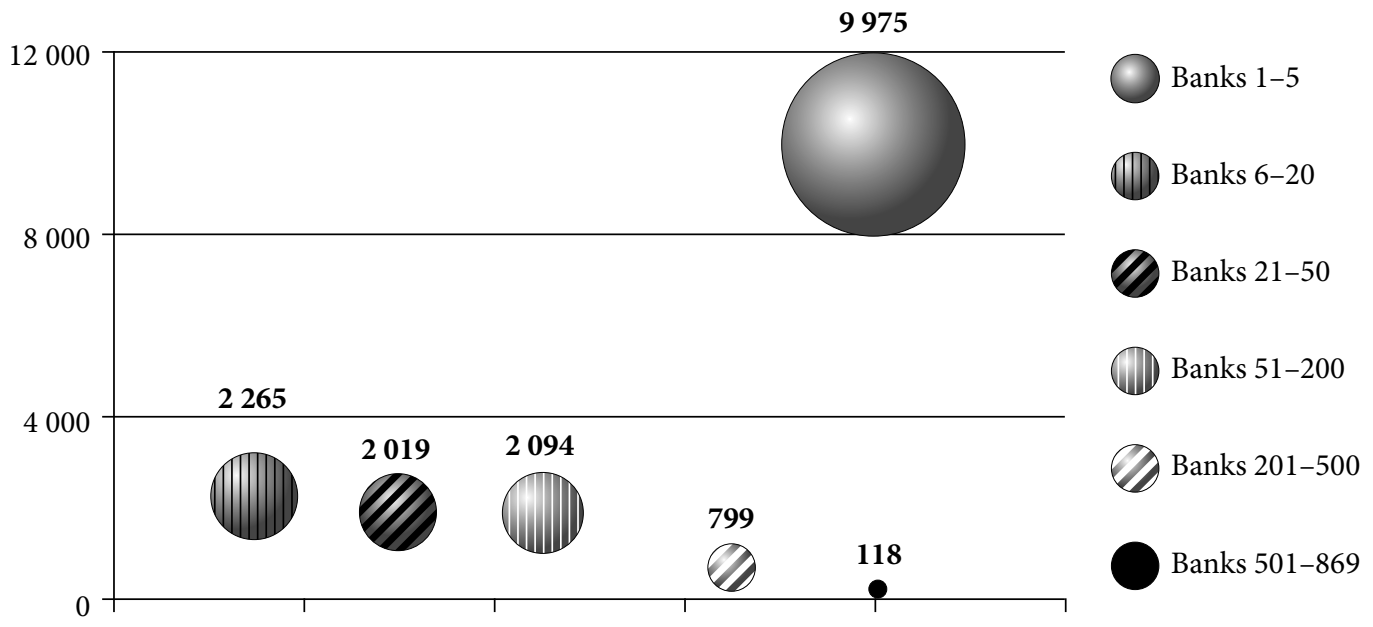

Source: Bank of Russia (2014d). 
2. There has been a decline in the capital adequacy ratios of the major banks (Mamonov, 2012), which leads to increasing risks in the banking system as a whole (Table 1). A key factor in the growth of risks is the complex macroeconomic situation and the international sanctions, which limit the ability of Russian banks to raise financial resources in foreign capital markets.

Table 1

\section{Capital adequacy ratio}

(H1 before 1/1/2014, H1.0 beginning 1/1/2014), \%

\begin{tabular}{|l|c|c|}
\hline \multicolumn{1}{|c|}{ Bank } & H1 as of $\mathbf{1 / 1 / 2 0 1 4}$ & H1.0 as of 9/1/2014 \\
\hline Sberbank & 12.96 & 12.24 \\
\hline VTB & 12.41 & 10.57 \\
\hline Gazprombank & 11.43 & 11.15 \\
\hline VTB-24 & 11.00 & 10.90 \\
\hline Bank of Moscow & 12.01 & 11.19 \\
\hline
\end{tabular}

Source: Bank of Russia (2014b).

3. Increase in past-due arrears on loans. Beginning in 2014 the quality of the credit portfolio gradually declined for the entire banking sector, and the share of past-due loans has risen. The increased share of past-due loans causes an increase in reserves, which in turn leads to a diminution of a bank's capital. Figure 3 shows the trend in past-due arrears.

\section{Share of past-due arrears (\% of credit portfolio)}

Figure 3

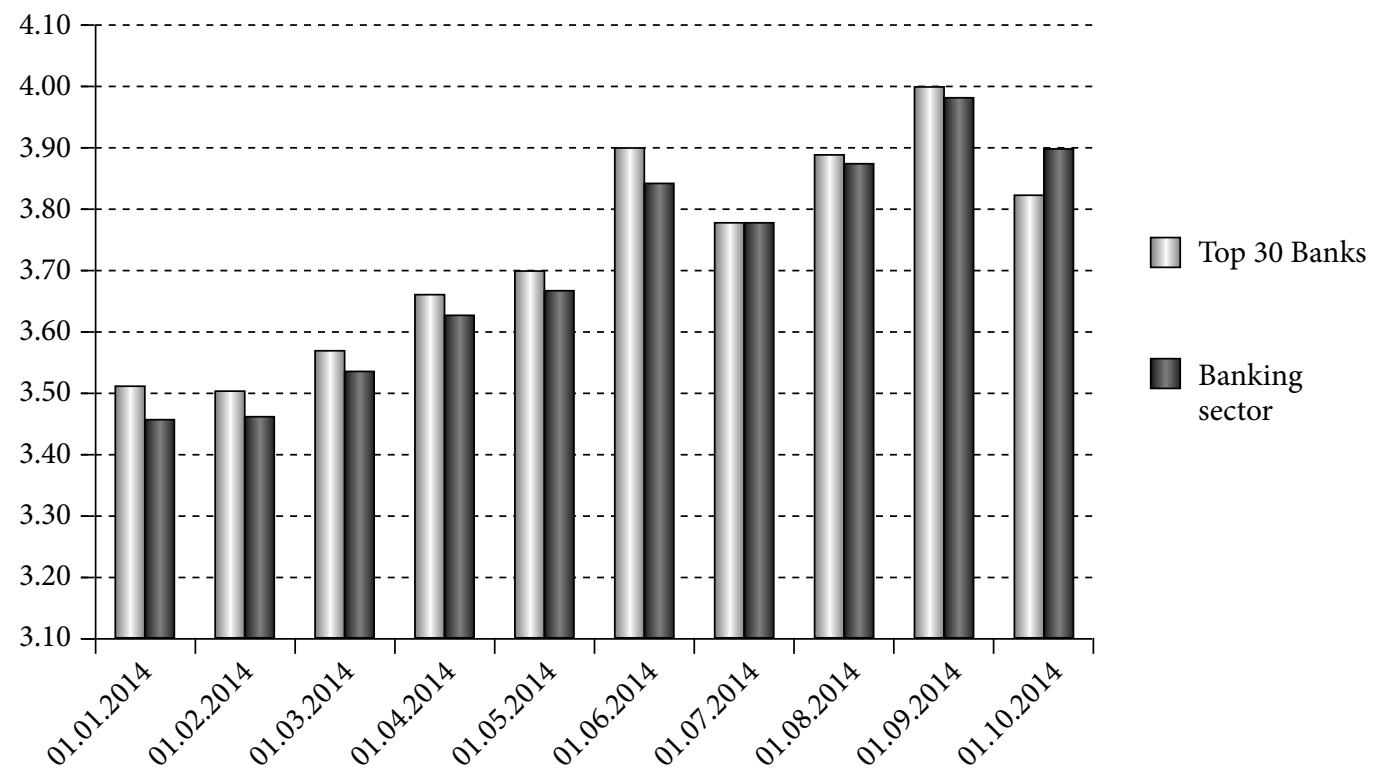

Source: Bank of Russia (2014e). 
As is clear from the graphs, the banking sector shows a steady growth in past-due loans. This causes a deterioration of the quality of the credit portfolio, growth of reserves for offsetting potential losses from loans and other assets, and a decline in the capital adequacy level (a decrease in the value of H1.0). The growth of banking reserves, however, lags far behind the growth rate of past-due loans, something that can be attributed to two factors. First, commercial banks seek to rid themselves of bad loans by putting them up for sale to collection agencies. Second, one cannot rule out possible manipulations of reports on current reserves in order to understate the risks associated with specific assets. The latter factor causes a deterioration of the quality of capital, which is difficult to assess for stakeholders, especially in an unstable economic environment. The dearth of information and difficulties in assessing risks result in increased transaction costs. In addition, it fosters distrust of available sources of information (financial statements) and encourages the arrangement of back-channels of communication between market actors and the regulator. For example, G.A. Tosunyan, the president of the Association of Russian Banks, points out: "There is a kind of chain of distrust in the sector today: the Bank of Russia does not trust banks enough; banks do not fully trust their customers; customers in response do not trust the banks or their counterparties; to all this is added the factor of mutual distrust between the banks and the law-and-order authorities, the courts. As a result, the circle closes and a system of total distrust forms" (Tosunyan, 2014).

One of the lines of tension is the question of regulation of the levels of equity capital. Initially, banking-sector regulators sought an aggregate performance indicator for commercial banks that could reflect the coverage ratio and, simultaneously, served as a marker for regulatory authorities, investors, shareholders and bank managers. The role of such a marker was originally assigned to the equity-capital level of a lending institution.

As of today, the situation has substantially changed, and the amount of bank capital is determined on the basis of the level of accepted risks. The regulatory authorities' logic is simple enough: if a bank's management plans to conduct high-risk operations, it should take care of increasing capital. It should be noted that there are a number of rules that limit the right of lending institutions with a low capital level to provide specific types of banking services. ${ }^{1}$ The central bank has set, effective January 1, 2015, a new minimum level of capital for banking institutions of 300 million rubles (Federal'nyi zakon, 2014). In addition, commercial banks are required to comply with the capital adequacy guideline (H1; and effective January 1, 2014, H1.0), which is calculated as the ratio of a bank's capital to its assets, weighted according to their risk level (Instruktsiia Banka Rossii, 2012).

Since 2013 the RF has pursued a policy of reducing the number of lending institutions. The regulator defines as one of the most important reasons for revoking a license "the pursuit of a high-risk credit policy and the failure to complete the establishment of loan-loss reserves that are adequate to accepted risks" (Ukazanie Banka Rossii, 2009). Table 2 shows a list of the banks whose licenses were revoked in 2014 (as of November 1, 2014). The following violations of accountability rules are usually cited as the official reasons for revoking the 
license: investing the funds of depositors and investors in low-quality assets, loss of solvency or the establishment of reserves below the necessary level.

Table 2

\section{List of banks whose licenses were revoked for conducting high-risk operations}

\begin{tabular}{|c|c|c|c|c|}
\hline $\begin{array}{c}\text { Commercial } \\
\text { bank }\end{array}$ & $\begin{array}{c}\text { Central } \\
\text { bank } \\
\text { license No. }\end{array}$ & $\begin{array}{l}\text { Date of revocation } \\
\text { of license to conduct } \\
\text { banking operations }\end{array}$ & $\begin{array}{l}\text { Level of capital as of } \\
\text { last reporting date } \\
\text { (thousands of rubles) }\end{array}$ & $\begin{array}{c}\text { Level of capital } \\
\text { adequacy ratio as of } \\
\text { last reporting date }\end{array}$ \\
\hline $\begin{array}{l}\text { Simbirsk } \\
\text { Regional } \\
\text { Bank OJSC }\end{array}$ & 653 & $11 / 11 / 2014$ & $\begin{array}{c}128.581 \\
(11 / 1 / 2014)\end{array}$ & 13.25 \\
\hline $\begin{array}{l}\text { IntrustBank } \\
\text { Joint Stock } \\
\text { Commercial } \\
\text { Bank OJSC }\end{array}$ & 3144 & $9 / 16 / 2014$ & $\begin{array}{c}1,906,849 \\
(9 / 1 / 2014)\end{array}$ & 14.62 \\
\hline $\begin{array}{l}\text { Fininvest } \\
\text { Bank LLC }\end{array}$ & 671 & $7 / 7 / 2014$ & $\begin{array}{c}2,176,182 \\
(7 / 1 / 2014)\end{array}$ & 10.56 \\
\hline $\begin{array}{l}\text { BFT Bank } \\
\text { Commercial } \\
\text { Bank LLC }\end{array}$ & 2273 & $6 / 2 / 2014$ & $\begin{array}{c}664,800 \\
(5 / 1 / 2014)\end{array}$ & 11.67 \\
\hline $\begin{array}{l}\text { Moscow } \\
\text { Lights } \\
\text { Commercial } \\
\text { Bank LLC }\end{array}$ & 2328 & $5 / 16 / 2014$ & $\begin{array}{c}-417,918 \\
(5 / 1 / 2014)\end{array}$ & 3.53 \\
\hline $\begin{array}{l}\text { First Republic } \\
\text { Bank OJSC }\end{array}$ & 1730 & $5 / 5 / 2014$ & $\begin{array}{c}4,264,928 \\
(4 / 1 / 2014)\end{array}$ & 10.71 \\
\hline $\begin{array}{l}\text { Western Bank } \\
\text { OJSC }\end{array}$ & 2598 & $4 / 21 / 2014$ & $\begin{array}{c}3,171,783 \\
(4 / 1 / 2014)\end{array}$ & 10.01 \\
\hline $\begin{array}{l}\text { European } \\
\text { Trust Bank } \\
\text { Commercial } \\
\text { Bank CJSC }\end{array}$ & 2968 & $2 / 11 / 2014$ & n.a. & n.a. \\
\hline My Bank LLC & 2939 & $1 / 31 / 2014$ & $\begin{array}{l}2,185,415 \\
(1 / 1 / 2014)\end{array}$ & 10.44 \\
\hline $\begin{array}{l}\text { Bank for } \\
\text { Project } \\
\text { Financing } \\
\text { Joint Stock } \\
\text { Bank CJSC }\end{array}$ & 1677 & $12 / 13 / 2013$ & $\begin{array}{c}3,569,001 \\
(12 / 1 / 2013)\end{array}$ & 13.99 \\
\hline $\begin{array}{l}\text { InvestBank } \\
\text { Joint Stock } \\
\text { Commercial } \\
\text { Bank OJSC }\end{array}$ & 107 & $12 / 13 / 2013$ & $\begin{array}{c}8,562,533 \\
(12 / 1 / 2013)\end{array}$ & 10.39 \\
\hline
\end{tabular}

Source: Bank of Russia (2014a).

It is clear from Table 2 that nine of the ten banks were meeting the requirements for the capital adequacy ratio. Eurotrust CB CJSC was not posting data on 
the capital level and the mandatory ratios at the central bank's official website. For four banks (Simbirsk Regional Bank OJSC; IntrustBank Joint Stock Commercial Bank OJSC; BFT Bank Commercial Bank LLC; and Bank for Project Financing Joint Stock Bank CJSC), the capital adequacy ratio was more than 11 percent, which indicates a capital reserve. For five banks on the list the capital adequacy ratio is between 10 percent and 11 percent, which is a signal of problems that the lending institution may have. If these indicators are compared with the amount of the capital adequacy ratio for the five largest Russian banks, we will not see any advantages for the latter.

Tables 3,4 , and 5 show the level of account balances and the change in capital held by banks during the period immediately prior to the license revocation.

Table 3

\section{Change in customer account balances prior to the license revocation, $\%$}

\begin{tabular}{|l|c|c|}
\hline \multicolumn{1}{|c|}{ Account type } & $\begin{array}{c}\text { Change during six months } \\
\text { prior to last reporting date }\end{array}$ & $\begin{array}{c}\text { Change during the month prior } \\
\text { to the last reporting date }\end{array}$ \\
\hline Current accounts of legal entities & -38 & -29 \\
\hline Current accounts of individuals & 7 & 14 \\
\hline $\begin{array}{l}\text { Time deposit accounts of legal } \\
\text { entities }\end{array}$ & -8 & -19 \\
\hline $\begin{array}{l}\text { Time deposit accounts of } \\
\text { individuals }\end{array}$ & -7 & -6 \\
\hline
\end{tabular}

Source: KUAP, 2014.

Change in capital and the H1.0 level, \%

\begin{tabular}{|l|c|c|}
\hline \multicolumn{1}{|c|}{ Indicator } & $\begin{array}{c}\text { Change during six months } \\
\text { prior to last reporting date }\end{array}$ & $\begin{array}{c}\text { Change during the month prior } \\
\text { to the last reporting date }\end{array}$ \\
\hline Capital & -12 & -17 \\
\hline H1.0 & -8 & -6 \\
\hline
\end{tabular}

Source: KUAP, 2014.

Obviously, the balances in the current accounts of legal entities are going down, while the balances in the current accounts of individuals are growing. The reason for this gap is that legal entities are better informed about the financial stability of the bank in which they are being served. But we should note that only in one of the listed banks (Simbirsk) were all of the funds withdrawn from the current accounts of legal entities. Among the banks in question, only in the European Trust Bank did the balances in the current accounts of legal entities rise from the previous month. The balances in the current accounts of individuals, conversely, increased on the average. At the Fininvest Bank, Investbank, 
and First Republic Bank, the balances in the deposit accounts of individuals rose for the six months prior to the revocation of the license. These banks were fairly large; their capital exceeded 2 billion rubles. The total amount of customers' funds as of the last reporting date for the banks in question was 200.645 trillion rubles, of which the deposit accounts of individuals accounted for 143.532 trillion rubles (Table 5).

To be sure, the regulator's revocation of licenses from problem banks is aimed at protecting depositors and creditors against financial losses. To create an atmosphere of trust, however, the regulator's actions must be implemented as part of a clear strategy that is approved by all the market participants. But if these tough measures are sporadic and not always understandable to market participants, the latter are more likely to become increasingly distrustful of small and medium-size banks, which promotes a re-allocation of customers' funds to the largest state-owned banks. In addition, in an environment of nontransparent regulatory policy investors, depositors and creditors use the most varied methods to obtain additional information, including rumors.

The H1.0 ratio reflects the bank's capital adequacy for covering risks, but it does not show the quality of risk management. Yet it is precisely this quality that determines a bank's financial stability. In addition, the risk management system should be included in all of the bank's key business processes. Riskmanagement tools must also be introduced both at the strategic and at the tactical levels of bank management. But the determination of risk, its probability and ways of responding are where continual interaction between the regulator and commercial banks is important. The regulator's requirements are not always in line with these tasks. One example is the stress-testing procedure, in which the central bank worked out only the most general and fairly ambiguous requirements for how to conduct it, which did not spell out either the scenario requirements or a minimum set of variables that were needed to create such a scenario (Pis'mo Banka Rossii, 2012). The banks, following the central bank's requirements, formulate internal statutes on stress-testing and a stress-testing procedure, but sometimes do so in a fairly perfunctory manner, without integrating it into strategic management. Hence there is a danger of reducing the role of risk management to the creation of an informational setting that is comfortable for the regulator, customers, and shareholders and creates a false impression that a company is financially stable and that there are opportunities for it to grow aggressively, which raises the proportion of high-risk operations even more (Lobanov, 2009).

In order to improve risk management at commercial banks, the regulator itself must switch to risk-oriented accountability. Bank-management experts note that the success of applying regulatory standards in order to minimize systemic risks and improve monitoring of their level depends on the effectiveness of the risk-oriented oversight process designed by the regulator (Kozyrev, 2013). Riskoriented regulation implies, on the one hand, an analysis of the change in the magnitude of risk when new regulatory rules are implemented and, on the other, the introduction of tools that encourage banks to introduce models of risk assessment into tactical and strategic management. 
$\frac{n}{\frac{0}{0}}$

\begin{tabular}{|c|c|c|c|c|c|c|c|c|c|c|c|c|}
\hline 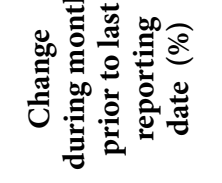 & $\begin{array}{l}\text { லे } \\
\text { iे }\end{array}$ & $\frac{\stackrel{0}{\vec{p}}}{i p}$ & $\frac{\stackrel{\circ}{0}}{\stackrel{1}{1}}$ & $\stackrel{\text { ले }}{\rightarrow}$ & 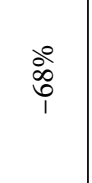 & $\begin{array}{l}\stackrel{0}{\circ} \\
\stackrel{\infty}{1} \\
1\end{array}$ & $\stackrel{\text { ì }}{\text { ì }}$ & $\underset{1}{\stackrel{\circ}{人}}$ & $\stackrel{\circ}{\stackrel{\circ}{1}}$ & $\stackrel{\text { ڤ̊ }}{ٍ}$ & 8̊ & $\stackrel{\circ}{\sim}$ \\
\hline 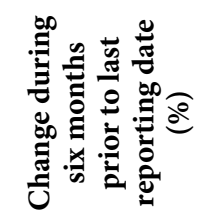 & $\begin{array}{l}\hat{\vartheta}_{0}^{\circ} \\
\text { }\end{array}$ & $\begin{array}{l}\stackrel{0}{\hat{0}} \\
\hat{b}^{1}\end{array}$ & $\underset{1}{\stackrel{0}{0}}$ & $\frac{\stackrel{2}{े}}{1}$ & $\frac{\dot{d}}{i}$ & 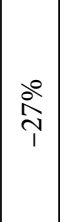 & i̊ & $\stackrel{\infty}{\infty}$ & $\frac{\grave{1}}{\grave{1}}$ & $\begin{array}{l}\stackrel{\circ}{\circ} \\
\stackrel{+}{+}\end{array}$ & ठ̊ & 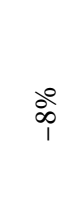 \\
\hline 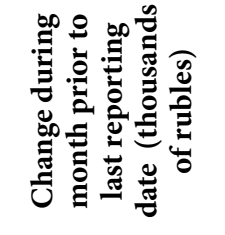 & 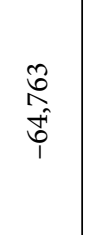 & $\begin{array}{l}m \\
\stackrel{n}{n} \\
\hat{n} \\
1\end{array}$ & $\begin{array}{l}\text { ్ָర } \\
\stackrel{i}{i}\end{array}$ & 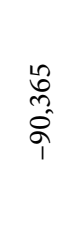 & $\begin{array}{l}\stackrel{N}{N} \\
\stackrel{0}{N} \\
i\end{array}$ & $\begin{array}{l}\stackrel{0}{N} \\
\stackrel{N}{N} \\
\stackrel{1}{1}\end{array}$ & $\begin{array}{l}\infty \\
\stackrel{\infty}{\circ} \\
= \\
F\end{array}$ & \begin{tabular}{l}
8 \\
\multirow{9}{1}{} \\
0 \\
0 \\
0 \\
$i$ \\
$i$
\end{tabular} & $\begin{array}{l}\hat{N} \\
\hat{\sigma} \\
\stackrel{\text { †े }}{1}\end{array}$ & $\begin{array}{l}\text { I } \\
\hat{-} \\
\hat{m}\end{array}$ & $\varphi_{1}$ & $\begin{array}{l}\infty \\
\stackrel{n}{n} \\
\hat{0}\end{array}$ \\
\hline 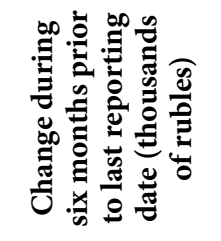 & 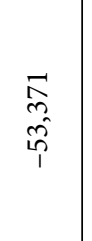 & $\begin{array}{l}\stackrel{2}{2} \\
\hat{\tilde{m}} \\
\stackrel{0}{1}\end{array}$ & $\begin{array}{l}\text { ָे } \\
1\end{array}$ & 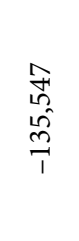 & 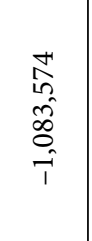 & $\begin{array}{l}\tilde{N} \\
0 \\
0 \\
0 \\
1\end{array}$ & $\begin{array}{l}0 \\
0 \\
\infty \\
0 \\
0 \\
1 \\
1\end{array}$ & $\begin{array}{l}\hat{i n} \\
\text { 命 } \\
\text { ô } \\
\text { i }\end{array}$ & 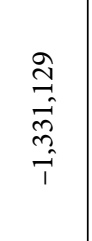 & $\begin{array}{l}\infty \\
\infty \\
\hat{\sim} \\
\hat{\imath}\end{array}$ & $\frac{8}{8}$ & $\begin{array}{l}\stackrel{\aleph}{\hat{~}} \\
\hat{\sigma} \\
\hat{\sigma}\end{array}$ \\
\hline 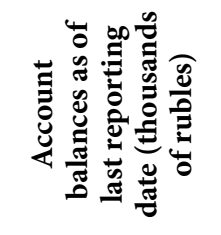 & $\begin{array}{l}\text { D } \\
\text { î } \\
\text { స̂ }\end{array}$ & $\begin{array}{l}\underset{N}{N} \\
\tilde{N}\end{array}$ & 0 & $\begin{array}{l}\hat{n} \\
\text { م̂ } \\
\hat{n}\end{array}$ & $\begin{array}{l}\stackrel{\hat{N}}{N} \\
\underset{F}{F}\end{array}$ & 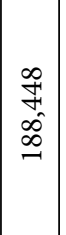 & 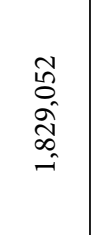 & $\begin{array}{l}\widetilde{6} \\
\hat{\sigma} \\
\infty \\
\infty \\
+1\end{array}$ & $\begin{array}{l}n \\
\overrightarrow{0} \\
\text { in } \\
\text { m }\end{array}$ & $\begin{array}{l}\infty \\
\infty \\
\infty \\
\hat{N}\end{array}$ & $\begin{array}{l}8 \\
8 \\
8 \\
8 \\
\text { in }\end{array}$ & $\begin{array}{l}\stackrel{2}{1} \\
\hat{\mathbb{N}} \\
\stackrel{n}{=} \\
=\end{array}$ \\
\hline 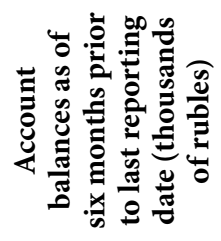 & $\begin{array}{l}\hat{n} \\
\hat{\delta} \\
\infty \\
\infty\end{array}$ & $\begin{array}{l}\vec{b} \\
\stackrel{0}{\sim}\end{array}$ & ర్రి & $\begin{array}{l}8 \\
0 \\
\text { N } \\
N\end{array}$ & 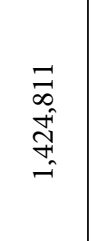 & $\begin{array}{l}8 \\
0 \\
0 \\
\infty \\
0 \\
n\end{array}$ & $\begin{array}{l}\text { ळे } \\
\text { ஸे } \\
\text { ڤે }\end{array}$ & $\begin{array}{l}2 \\
\infty \\
\hat{\varnothing} \\
\text { ஸे }\end{array}$ & \begin{tabular}{l}
\multirow{+}{*}{} \\
6 \\
$\hat{0}$ \\
0 \\
-1
\end{tabular} & 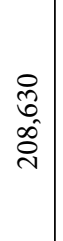 & $\begin{array}{l}8 \\
\dot{0} \\
i \\
i \\
i n\end{array}$ & 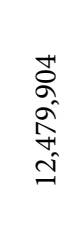 \\
\hline 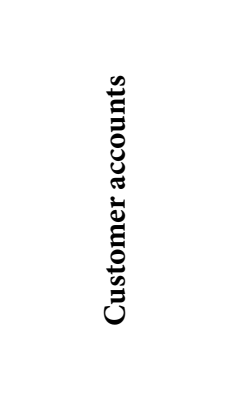 & 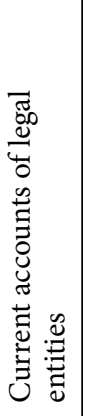 & 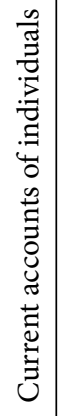 & 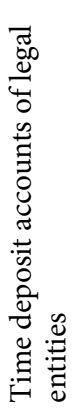 & 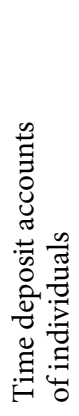 & 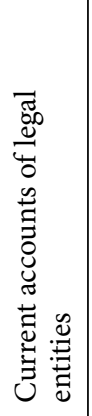 & 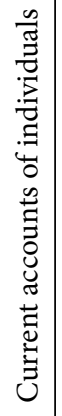 & 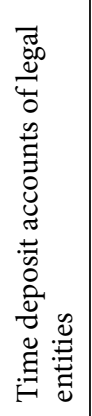 & 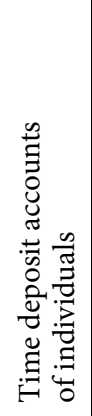 & 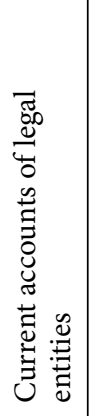 & 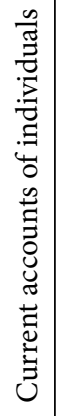 & 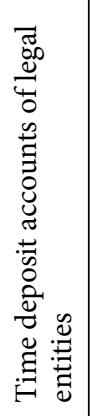 & 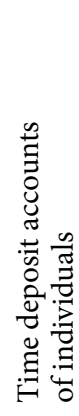 \\
\hline 唇 & 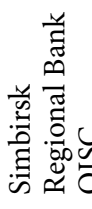 & & & & \multicolumn{4}{|c|}{ 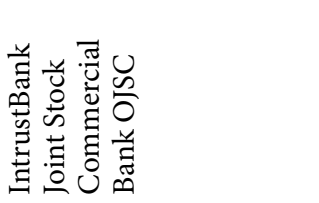 } & \multicolumn{4}{|l|}{ 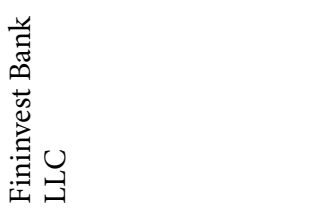 } \\
\hline
\end{tabular}




\begin{tabular}{|c|c|c|c|c|c|c|c|c|c|c|c|c|c|c|c|}
\hline$\stackrel{\infty}{\stackrel{\infty}{1}}$ & ठ̊ & $\stackrel{\stackrel{0}{\rightarrow ~}}{\uparrow}$ & ठ̊ & $\stackrel{\text { ì }}{i}$ & ले & $\stackrel{\circ}{\stackrel{1}{1}}$ & $\stackrel{\circ}{1}$ & 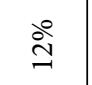 & $\stackrel{\circ}{\grave{1}}$ & @̊ & $\stackrel{\text { ஸे }}{\text { ì }}$ & $\stackrel{\text { \} }{\stackrel{1}{~}}} &{\text { مे }} &{\text { 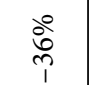 }} &{\text { 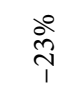 }} \\
{\hline \text { ล̊ }} &{\stackrel{\stackrel{े}{1}}{\underset{1}{1}}} &{\frac{\stackrel{0}{\stackrel{1}{1}}}{1}} &{\stackrel{\text { }}{\stackrel{0}{ }}} &{\stackrel{\substack{i \\
i}}{i}} &{\stackrel{\stackrel{2}{1}}{1}} &{\stackrel{\circ}{\stackrel{0}{\circ}}} &{\stackrel{\circ}{\circ}} &{\stackrel{\circ}{\stackrel{\circ}{\dagger}}} &{\begin{array}{l}\stackrel{0}{0} \\
\hat{i} \\
1\end{array}} &{\stackrel{\stackrel{े}{\sim}}{ }} &{\stackrel{\text { సิ }}{\text { }}} &{\stackrel{\text { ले }}{\stackrel{p}{p}}} &{\text { ㅇํㅅ }} &{\frac{\partial^{\circ}}{F}} &{\begin{array}{l}\stackrel{0}{0} \\
\stackrel{1}{1}\end{array}} \\
{\hline \text { 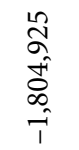 }} &{\text { 萭 }} &{\begin{array}{l}\tilde{\delta} \\
\stackrel{\tilde{T}}{\tau} \\
\hat{i}\end{array}} &{\text { 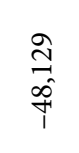 }} &{\begin{array}{l}\infty \\
\hat{n} \\
0 \\
b^{\circ} \\
\stackrel{1}{1}\end{array}} &{\begin{array}{l}\stackrel{2}{\tilde{N}} \\
\hat{\sim}\end{array}} &{\text { 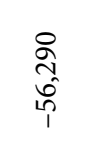 }} &{\begin{array}{l}\vec{D} \\
\sim \\
\delta \\
\stackrel{1}{1} \\
i\end{array}} &{\text { 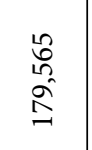 }} &{\begin{array}{l}\hat{0} \\
\hat{N} \\
\hat{i}\end{array}} &{\begin{array}{l}\stackrel{9}{5} \\
\hat{a} \\
\Rightarrow\end{array}} &{\begin{array}{l}0 \\
\hat{\delta} \\
00 \\
0 \\
1\end{array}} &{\begin{array}{l}8 \\
\infty \\
\omega^{2} \\
\hat{\sim} \\
0 \\
1\end{array}} &{\begin{array}{l}\vec{F} \\
\stackrel{F}{\hat{m}}\end{array}} &{\text { 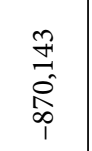 }} &{\text { 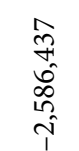 }} \\
{\hline \begin{array}{l}\infty \\
\infty \\
\infty \\
\hat{n} \\
\hat{n} \\
\hat{1}\end{array}} &{\begin{array}{l}\stackrel{2}{N} \\
\underset{\sim}{2} \\
\stackrel{\sim}{1}\end{array}} &{\overrightarrow{\tilde{n}}} &{\text { 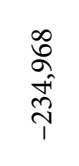 }} &{\text { 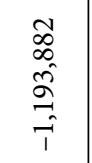 }} &{\text { 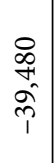 }} &{\begin{array}{l}\stackrel{o}{o} \\
\text { n̂ } \\
\text { م̂ }\end{array}} &{\begin{array}{l}\vec{J} \\
\vec{\Xi} \\
\stackrel{\mathbb{N}}{-}\end{array}} &{\text { 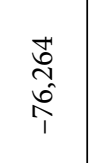 }} &{\begin{array}{l}0 \\
\hat{\sigma} \\
0 \\
\vdots \\
\hat{0} \\
1\end{array}} &{\text { 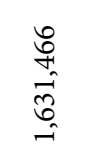 }} &{\text { 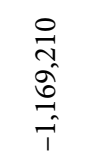 }} &{\begin{array}{l}\stackrel{m}{\cong} \\
\vec{f} \\
\stackrel{-}{1}\end{array}} &{\text { 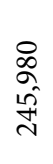 }} &{\begin{array}{l}8 \\
8 \\
\hat{~} \\
0 \\
\hat{i} \\
\hat{i}\end{array}} &{\text { 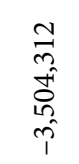 }} \\
{\hline \begin{array}{l}\infty \\
\infty \\
\infty \\
\text { N̂} \\
\text { n̂ }\end{array}} &{\text { 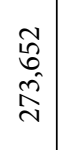 }} &{\text { 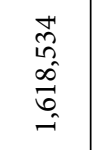 }} &{\text { 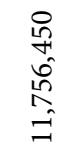 }} &{\text { 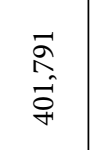 }} &{\text { 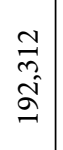 }} &{\begin{array}{l}\infty \\
\infty \\
\infty \\
\tilde{N} \\
\stackrel{-}{-}\end{array}} &{\begin{array}{l}\tilde{\sigma} \\
\hat{\alpha} \\
\text { oे } \\
\tilde{\omega} \\
\hat{\sim}\end{array}} &{\text { 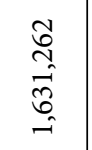 }} &{\text { 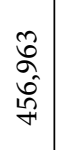 }} &{\begin{array}{l}\tilde{o} \\
\tilde{\delta} \\
\hat{\delta} \\
\infty \\
\infty \\
\infty\end{array}} &{\begin{array}{l}\infty \\
\infty \\
\infty \\
\curvearrowright \\
\stackrel{+}{-}\end{array}} &{\begin{array}{l}\vec{\infty} \\
\hat{N} \\
\hat{\tilde{N}} \\
\hat{\sim}\end{array}} &{\text { 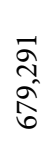 }} &{\text { 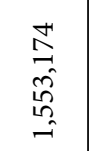 }} &{\begin{array}{l}\text { fे } \\
\text { के } \\
\infty \\
8 \\
\infty \\
\infty\end{array}} \\
{\hline \begin{array}{l}\overrightarrow{0} \\
\stackrel{0}{0} \\
\stackrel{0}{0} \\
\hat{i}\end{array}} &{\begin{array}{l}\hat{\hat{a}} \\
\hat{\hat{I}} \\
\hat{+}\end{array}} &{\text { 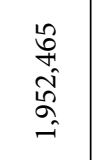 }} &{\begin{array}{l}\infty \\
\vec{\sigma} \\
\hat{\sigma} \\
= \\
=\end{array}} &{\begin{array}{l}\hat{n} \\
\hat{0} \\
\hat{2} \\
\hat{n} \\
\rightarrow\end{array}} &{\begin{array}{l}\hat{\Omega} \\
\hat{\vec{n}} \\
\text { in }\end{array}} &{\begin{array}{l}\stackrel{0}{~} \\
\multirow{2}{*}{} \\
\multirow{2}{*}{}\end{array}} &{\begin{array}{l}\hat{O} \\
\infty \\
\hat{0} \\
0 \\
\hat{i}\end{array}} &{\begin{array}{l}\stackrel{0}{2} \\
\hat{2} \\
\hat{0} \\
\stackrel{-}{-}\end{array}} &{\text { 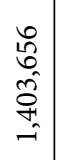 }} &{\begin{array}{l}8 \\
\stackrel{0}{n} \\
\hat{N} \\
\hat{\sigma} \\
\hat{0}\end{array}} &{\begin{array}{l}\infty \\
0 \\
0 \\
\stackrel{2}{1} \\
m \\
i n\end{array}} &{\begin{array}{l}\hat{\sigma} \\
\hat{\tilde{F}} \\
\hat{m} \\
\hat{m}\end{array}} &{\begin{array}{l}= \\
\vec{m} \\
\hat{\vartheta} \\
\vec{f}\end{array}} &{\begin{array}{l}\stackrel{+}{N} \\
i s \\
\multirow{2}{0}{} \\
i \\
\hat{i}\end{array}} &{\text { 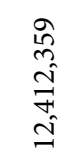 }} \\
{\hline \text { 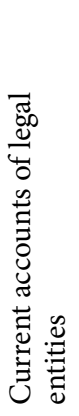 }} &{\text { 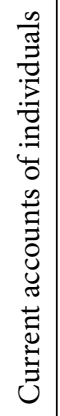 }} &{\text { 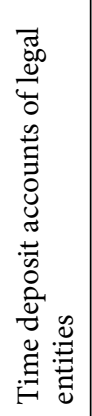 }} &{\text { 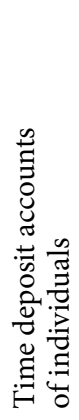 }} &{\text { 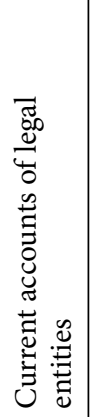 }} &{\text { 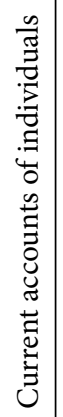 }} &{\text { 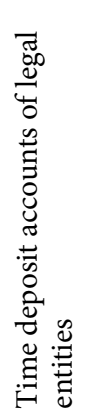 }} &{\text { 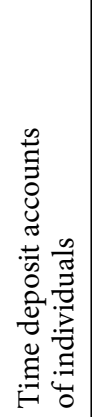 }} &{\text { 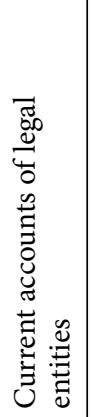 }} &{\text { 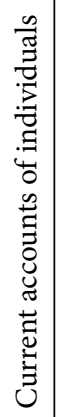 }} &{\text { 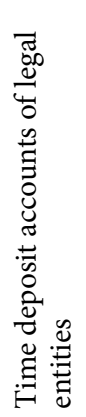 }} &{\text { 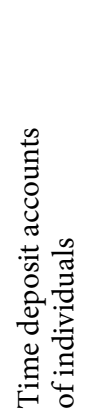 }} &{\text { 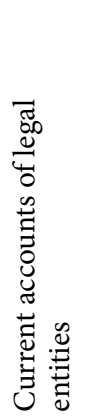 }} &{\text { 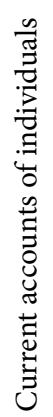 }} &{\text { 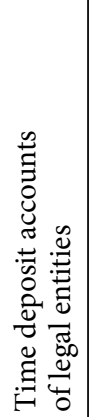 }} &{\text { 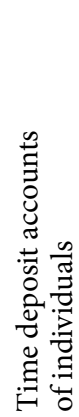 }} \\
{\hline \multicolumn{4}{|c|}{\text { 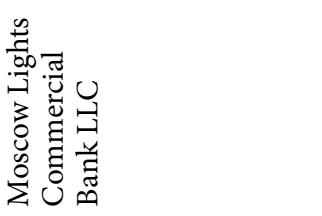 }}\text { 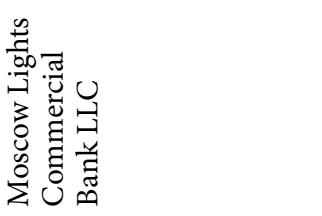 }} &{\multicolumn{4}{|l|}{\text { 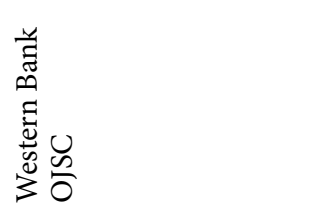 }}\text { 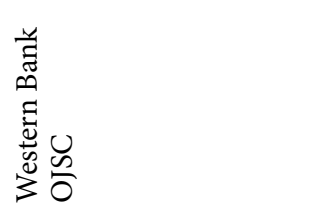 }} &{\multicolumn{4}{|c|}{\text { 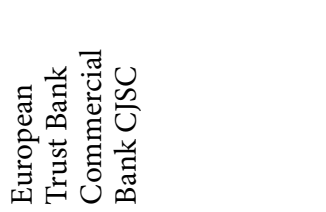 }}\text { 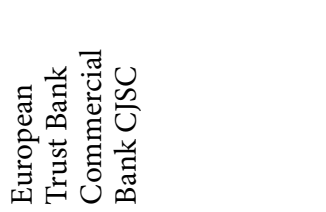 }} &{\multicolumn{4}{|l|}{\text { 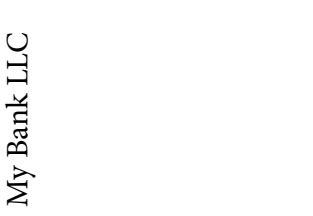 }}\text { 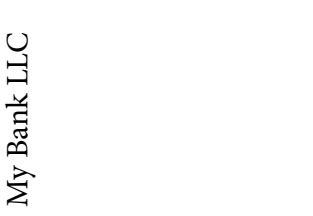 }} \\
$\hline
\end{tabular}




\begin{tabular}{|c|c|c|c|c|c|c|c|c|c|c|c|c|c|c|c|}
\hline$\stackrel{\text { mे }}{\text { pे }}$ & î̀ & $\stackrel{\circ}{\stackrel{0}{1}}$ & बें & ì̀ & i̊ & $\stackrel{\circ}{\stackrel{1}{0}}$ & $\stackrel{े}{\grave{~}}$ & $\frac{\circ}{1}$ & $\stackrel{\stackrel{\circ}{+}}{+}$ & $\frac{\stackrel{0}{p}}{p}$ & $\frac{\circ}{1}$ & $\stackrel{\text { ڤे }}{\stackrel{0}{े}}$ & $\stackrel{\circ}{ٍ}$ & $\stackrel{\circ}{\stackrel{\circ}{~}}$ & $\therefore$ \\
\hline $\begin{array}{l}\text { 8े } \\
0 \\
1\end{array}$ & ồ & $\stackrel{\circ}{=}$ & 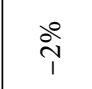 & $\stackrel{\circ}{\Rightarrow}$ & 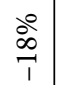 & $\stackrel{\stackrel{\circ}{\stackrel{1}{1}}}{ }$ & î & $\stackrel{\circ}{+}$ & $\stackrel{\circ}{1}$ & 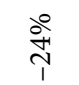 & 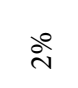 & $\stackrel{\circ}{\stackrel{9}{ }}$ & $\stackrel{8}{0}$ & ָे & $\stackrel{\circ}{\wedge}$ \\
\hline $\begin{array}{l}\text { ñ } \\
\hat{\alpha} \\
\hat{N} \\
\hat{1}\end{array}$ & $\begin{array}{l}\tilde{n} \\
m \\
\hat{n} \\
\hat{n}\end{array}$ & $\begin{array}{l}8 \\
\stackrel{0}{1} \\
\stackrel{0}{1}\end{array}$ & 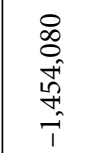 & $\begin{array}{l}n \\
\hat{n} \\
\hat{n} \\
0 \\
0 \\
0 \\
i\end{array}$ & $\begin{array}{l}0 \\
\ell_{0} \\
\delta \\
0 \\
1\end{array}$ & $\begin{array}{l}10 \\
0 \\
0 \\
0 \\
0 \\
0 \\
i \\
i\end{array}$ & $\begin{array}{l}\infty \\
0 \\
0 \\
0 \\
\hat{n}\end{array}$ & $\begin{array}{l}\hat{0} \\
\stackrel{m}{1} \\
\stackrel{1}{1}\end{array}$ & \begin{tabular}{l}
$\stackrel{+}{6}$ \\
$\stackrel{+}{ \pm}$ \\
\multirow{-}{*}{}
\end{tabular} & $\begin{array}{l}\mathbb{N} \\
\hat{\overbrace{}} \\
\hat{\imath}\end{array}$ & 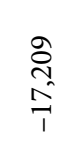 & 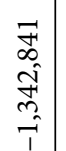 & $\begin{array}{l}n \\
0 \\
\hat{n} \\
\text { nी }\end{array}$ & $\begin{array}{l}\hat{\alpha} \\
\hat{i n} \\
\hat{\sigma} \\
\hat{1}\end{array}$ & $\begin{array}{l}\stackrel{8}{0} \\
\hat{n} \\
n \\
n\end{array}$ \\
\hline 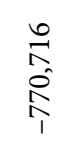 & $\begin{array}{l}n \\
\infty \\
\infty \\
\hat{\Lambda}\end{array}$ & $\begin{array}{l}\infty \\
\infty \\
\stackrel{\infty}{\sim} \\
\vec{\sim}\end{array}$ & $\begin{array}{l}8 \\
0 \\
0 \\
0 \\
1\end{array}$ & $\begin{array}{l}\infty \\
\infty \\
\infty \\
0 \\
0 \\
i \\
i\end{array}$ & 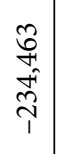 & 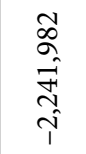 & 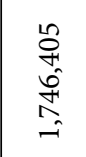 & $\begin{array}{l}\text { L } \\
\text { nิ } \\
8 \\
0 \\
1\end{array}$ & $\underset{⿱}{\stackrel{+}{0}}$ & 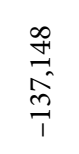 & $\begin{array}{l}\text { 岁 } \\
\stackrel{\text { in }}{\vec{N}}\end{array}$ & 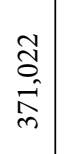 & $\begin{array}{l}\overrightarrow{+} \\
\stackrel{5}{ } \\
\infty\end{array}$ & 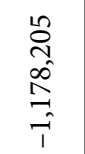 & 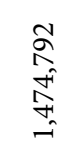 \\
\hline $\begin{array}{l}\vec{n} \\
\hat{n} \\
\vec{n}\end{array}$ & 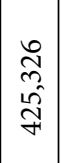 & 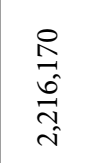 & 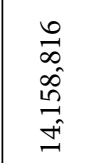 & 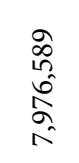 & $\begin{array}{l}\hat{N} \\
0 \\
\hat{N} \\
\hat{0} \\
0 \\
-1\end{array}$ & $\begin{array}{l}m \\
\infty \\
\infty \\
\infty \\
\hat{0} \\
0\end{array}$ & $\begin{array}{l}\text { ते } \\
\hat{\omega} \\
\hat{\sigma} \\
\text { مे } \\
\text { ले }\end{array}$ & $\begin{array}{l}\text { N } \\
\hat{n} \\
8 \\
0 \\
0 \\
\hat{i}\end{array}$ & $\begin{array}{l}\text { ป } \\
\cong \\
\Xi\end{array}$ & \begin{tabular}{l} 
Oे \\
$\infty$ \\
\multirow{f}{f}{}
\end{tabular} & $\begin{array}{l}\stackrel{H}{+} \\
0 \\
\overrightarrow{0} \\
\stackrel{-1}{-1}\end{array}$ & 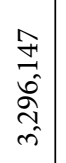 & $\begin{array}{l}\tilde{B} \\
0 \\
8 \\
0 \\
i n\end{array}$ & $\begin{array}{l}0 \\
\text { h } \\
6 \\
0 \\
0 \\
+1\end{array}$ & $\begin{array}{l}\infty \\
0 \\
0 \\
0 \\
0 \\
+ \\
\text { in }\end{array}$ \\
\hline 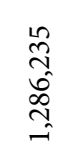 & $\begin{array}{l}\vec{\Xi} \\
\tilde{\hat{N}} \\
\stackrel{f}{1}\end{array}$ & $\begin{array}{l}20 \\
\infty \\
10 \\
8 \\
8 \\
i \\
i\end{array}$ & 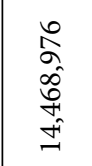 & $\begin{array}{l}\infty \\
\infty \\
\infty \\
0 \\
0 \\
i\end{array}$ & $\begin{array}{l}\stackrel{2}{2} \\
\tilde{n} \\
\stackrel{\sim}{N} \\
\stackrel{-}{n}\end{array}$ & 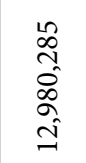 & $\begin{array}{l}\stackrel{n}{=} \\
\stackrel{n}{2} \\
\stackrel{2}{n}\end{array}$ & $\begin{array}{l}\hat{0} \\
\hat{1} \\
\hat{+} \\
\hat{i} \\
\hat{i}\end{array}$ & 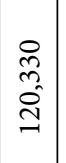 & $\begin{array}{l}\infty \\
\hat{\alpha} \\
\stackrel{\infty}{\infty} \\
i n\end{array}$ & 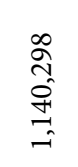 & 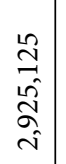 & $\begin{array}{l}\infty \\
\stackrel{0}{1} \\
\overrightarrow{0} \\
\stackrel{+}{+}\end{array}$ & 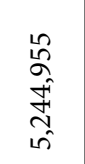 & 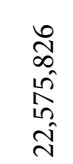 \\
\hline 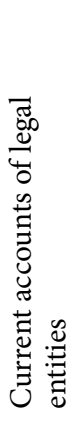 & 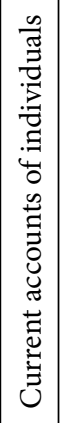 & 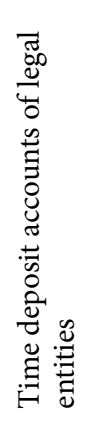 & 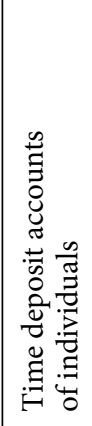 & 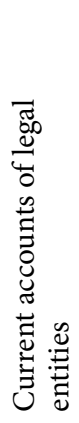 & 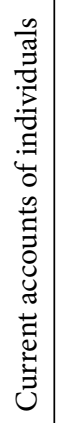 & 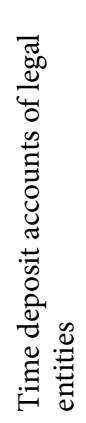 & 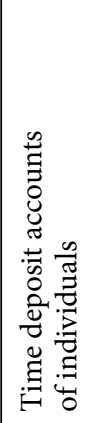 & 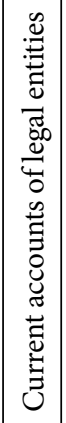 & 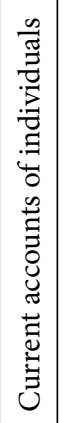 & 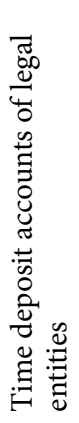 & 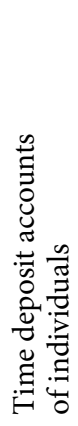 & 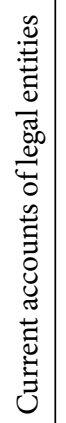 & 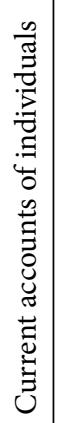 & 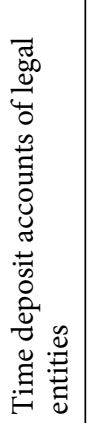 & 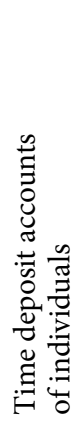 \\
\hline \multicolumn{4}{|c|}{ 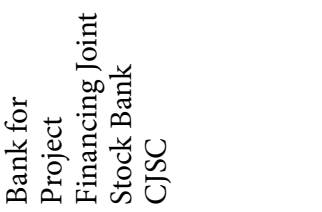 } & \multicolumn{4}{|c|}{ 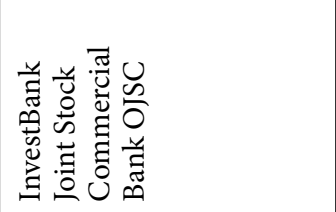 } & \multicolumn{4}{|c|}{ 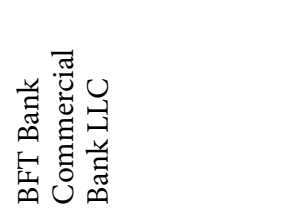 } & \multicolumn{4}{|c|}{ 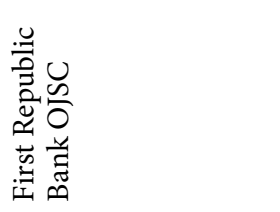 } \\
\hline
\end{tabular}

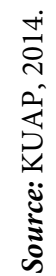




\section{Conclusions}

The implementation of new regulatory rules, often unexpected and unclear to agents of the market, runs into resistance (capital flight, abandonment of long-term investment projects, withdrawal of companies into the shadows), which creates new lines of tension that require the next round of tightening of rules by the regulator. In an environment where the delegated accountability model is dominant, the contradiction between the latter and the economic effectiveness of regulatory policy is exacerbated. The traditional task of deregulation is replaced by the need to design continuously functioning and transparent channels of communications between the regulator and the regulated. An analysis of the functioning of the tightly restrictive accountability mechanism in the banking sector shows the risks of the delegation model in an environment of weak institutions. Therefore the task of regulation in a country where institutional hybrids are dominant is to change from design-basis and reactive to reflexive standardization, when the priorities of regulatory policy (in the absence of a clearly formulated government strategy) shift from unilateral administrative rulemaking and the implementation of decisions to the creation of institutions of interaction as part of a new accountability model that is more oriented toward participation. As a result, it is recommended that the problem of the regulator's discretionary powers be solved through the partial de-statization of the accountability relationship, where, as shown in the banking-sector examples, a system can be designed whereby commercial banks and stakeholders participate in the regulation of the banking sector by changing from reactive regulation to a practice of institutionally designed interaction. Under this model it is possible to create accountability mechanisms that can strike a balance between managing risks at a specific commercial bank and risk-oriented regulation. A hybrid accountability model is more in line with the task of maintaining competition in an environment of weak institutions. It limits the ability of the largest banks to unilaterally influence the regulator and thereby lowers the systemic risks of the banking sector. 


\section{REFERENCES}

1. Artemyev, A.A. (2010). Razvitie institutsional'noy sistemy regulirovaniya bankovskogo sektora Rossii [Development of an Institutional System of Regulation of Russia's Banking Sector]. St. Petersburg: St. Petersburg State University.

2. Bank of Russia (2014). Baza dannykh po press-relizam [Data base of press releases]. Available: http://www.cbr.ru/Press/?PrtId=press_archive (accessed: 11/26/2014).

3. Bank of Russia (2014). Informatsiya ob obyazatel'nykh normativakh i o drugikh pokazatelyakh deyatel'nosti kreditnoy organizatsii [Information About Mandatory Ratios and Other Performance Indicators of Lending Institutions]. Available: http://www. cbr.ru/credit/main.asp (accessed: 11/22/2014).

4. Bank of Russia (2014). Ob otzyve litsenzii na osushchestvlenie bankovskikh operatsiy i naznachenii vremennoy administratsii [Revocation of Licenses to Conduct Banking Operations and the Appointment of a Temporary Administration]. Available: http://www.cbr.ru/press/PR.aspx?file=11112014_083717ik2014-11-11T08_34_34. htm (accessed: 11/25/2014).

5. Bank of Russia (2014). Otdel'nye pokazateli deyatel'nosti kreditnykh organizatsiy, sgruppirovannykh po velichine aktivov, po sostoyaniyu na 1 sentyabrya $2014 \mathrm{~g}$. [Selected Performance Indicators of Lending Institutions, Grouped According to Amount of Assets, as of September 1,2014]. Available: http://www.cbr.ru/statistics/ print.aspx?file=bank_system/4-1-3_010914.htm\&pid=pdko_sub\&sid=opdkovo (accessed: 11/22/2014).

6. Bank of Russia (2014). Svodnaya statisticheskaya informatsiya po krupneyshim bankam [Consolidated Statistical Information on Major Banks]. Available: http://www.cbr.ru/analytics/?PrtId=bnksyst (accessed: 11/23/2014).

7. Dodd-Frank Act Stress Test 2013: Supervisory Stress Test Methodology and Results. Board of Governors of the Federal Reserve System, March 2013. Available: http://www. federalreserve.gov/newsevents/press/bcreg/dfast_2013_results_20130314.pdf. (accessed: 04/16/2014).

8. Federalnyi zakon ot 10.07.2002 N 86-FZ (red. ot 04.11.2014) «O Tsentral'nom banke Rossiyskoy Federatsii (Banke Rossii)» (10 iyulya 2002 g.) [Federal Law No. 86-FZ dated 7/10/2002 (as amended on 11/4/2014) «On the Central Bank of the Russian Federation (Bank of Russia)» (July 10, 2002)]. Available: http://www.consultant.ru/ document/cons_doc_LAW_170640/(accessed: 11/25/2014).

9. Grant, R.W. \& Keohane, R.O. (2005). Accountability and Abuses of Power in World Politics. American Political Science Review, vol. 99, n. 1, pp. 29-43.

10. Instruktsiya Banka Rossii ot 03.12.2012 N 139-I (red. ot 30.09.2014) «Ob obyazatelnykh normativakh bankov» (Zaregistrirovano v Minyuste Rossii 13.12 .2012 N 26104) (03 dekabrya 2012 g.) [Instructions of the Bank of Russia dated 12/3/2012, No. 139 (as amended 9/30/2014) «On Mandatory Ratios of Banks» (Registered with the Ministry of Justice of Russia 12/13/2012, No. 26104) (December 3, 2012)]. 
Available: http://www.consultant.ru/document/cons_doc_LAW_170221 (accessed: $11 / 25 / 2014)$.

11. Khillman [Hillman], A. (2009). Gosudarstvo i ekonomicheskaya politika: vozmozhnosti i ogranicheniya upravleniya [The State and Economic Policy: The Capabilities and Constraints of Management]. Moscow: HSE.

12. Kozyrev, N.A., Popov, O.V., et al. (2013). Pozvolit li realizatsiya rekomendatsiy Bazel'skogo komiteta kontrolirovat' riski? [Will the Implementation of the Recommendations of the Basel Committee Make it Possible to Control Risks?]. Upravlenie $v$ kreditnoy organizatsii, n. 1, pp. 21-27.

13. KUAP. Finansovyi analiz. Bank of Russia. (2014). Baza dannykh po rossiyskim bankam, bankovskaya otchetnost' [Database on Russian Banks, Bank statements]. Available: http://kuap.ru/banks/ (accessed: 11/23/2014).

14. Lobanov, A.A., Chugunov, A.V. (2009). Entsiklopediya finansovogo risk-menedzhmenta [Encyclopedia of Financial Risk Management]. Moscow: Alpina Business Books.

15. Mamonov, M.E. et al. (2012). Otsenka sistemnykh effektov ot uzhestocheniya prudentsial'nogo regulirovaniya bankovskogo sektora: rezul'taty stress-testa [Evaluation of Systemic Effects From the Tightening of Prudential Regulation of the Banking Sector: Results of a Stress test]. Voprosy ekonomiki, n. 8, pp. 4-31.

16. Oakerson, R.J. (1989). Governance Structures for Enhancing Accountability and Responsiveness. Handbook of Public Administration (Ed. by James L. Perry). San Francisco: Jossey-Bass.

17. Olsen, J.P. (2010). Governing through Institution Building: Institutional Theory and Recent European Experiments in Democratic Organization. New York: Oxford University Press.

18. Pis'mo Banka Rossii ot 29.12.2012 N 192-T "O Metodicheskikh rekomendatsiyakh po realizatsii podkhoda $k$ raschetu kreditnogo riska na osnove vnutrennikh reytingov bankov" [Letter No. 192-T of the Bank of Russia dated 12/29/2012 «On Methodological Recommendations for Implementing an Approach to the Calculation of Credit Risk Based on Internal Ratings of Banks»]. Available: http://www.consultant.ru/document/cons_doc_LAW_140871 (accessed: 11/25/2014).

19. Risk-menedzhment $v$ kommercheskom banke [Risk Management in a Commercial Bank] (Ed. by I.V. Larionova). Moscow: KNORUS, 2014.

20. Sinkey, J., Jr. (2007). Finansovyy menedzhment $v$ kommercheskom banke i $v$ industrii finansovykh uslug [Commercial Bank Financial Management in the Financial Services Industry]. Moscow: Alpina Publisher.

21. The Tools of Government: A Guide to The New Governance (Ed. by L.M. Salamon). New York: Oxford University Press, 2002.

22. Timofeeva, Z.A. (2012). K voprosu o modernizatsii rossiyskoy bankovskoy sistemy [The Question of Modernizing the Russian Banking System]. Dengi i kredit, n. 9. pp. 44-49. 
23. Tosunyan, G.A. (2014). O perspektivakh bankovskoy sistemy Rossii: vzglyad bankovskogo soobshchestva [The Outlook for Russia’s Banking System: The Banking Community's View]. Dengi i kredit, n. 5. pp. 5-7.

24. Ukazanie Banka Rossii ot 12 noyabrya 2009 g. N 2332-U «O perechne, formakh $i$ poryadke sostavleniya $i$ predstavleniya form otchetnosti kreditnykh organizatsiy $v$ Tsentral'nyy bank Rossiyskoy Federatsii» (s izmeneniyami i dopolneniyami) [Directive of the Bank of Russia dated November 12, 2009 No. 2332-U «On the List, Forms and Procedure for Compiling and Submitting Forms of Statements of Lending Institutions to the Central Bank of the Russian Federation» (With Amendments and Additions)]. Available: http://base.garant.ru/12171690/ (accessed: 11/25/2014).

25. Vine, S. (2014). Optimizatsiya resursov banka [Optimizing Bank Resources]. Moscow: Alpina Publisher.

26. Zrazhevskiy, V.V. (2007). O stabil'nosti bankovskoy sistemy [On the Stability of the Banking System]. Dengi i kredit, n. 2, pp. 35-39.

\section{NOTE}

1 For example, Federal Law No. 44 "On the Contract System in the Sphere of Purchases, Goods, Work, and Services to Meet National and Municipal Needs," adopted in 2013, limits, for banks with less than 1 billion rubles in capital, the issuance of guarantees to companies participating in government contracts. 